\title{
Insulin-like growth factors and IGF binding proteins in cyst fluid from patients with craniopharyngioma prior to intracavitary irradiation with ${ }^{90}$ Yttrium and thereafter
}

\author{
W Zumkeller, M Sääf, T Rähn
}

\begin{abstract}
Aim-To examine a series of cyst fluid samples from patients with craniopharyngioma at various stages of treatment in order to evaluate the use of insulin-like growth factors (IGFs) and IGF binding proteins as tumour markers or indicators of successful treatment, or both. Methods-Cyst fluid samples were obtained by stereotactic puncture prior to the intracavitary application of ${ }^{90}$ Yttrium and at subsequent occasions. Analysis was performed by gel chromatography, radioimmunoassays, binding studies, and sodium dodecyl sulphate-polyacrylamide gel electrophoresis (SDS-PAGE) with subsequent western blotting.
\end{abstract}

Results-IGF-I, -II and IGF binding protein-1 concentrations were measured in three craniopharyngioma cyst fluid samples. Immunoreactive IGF-I and IGF binding protein- 1 concentrations in these three samples were between 6 and $29 \mathrm{ng}$ / $\mathrm{ml}$, and 17 and $48 \mathrm{ng} / \mathrm{ml}$, respectively. In contrast, the IGF-II concentrations measured in 19 cyst fluid samples from seven patients with craniopharyngioma at various stages of treatment were much higher at $25-671 \mathrm{ng} / \mathrm{ml}$. SDS-PAGE and subsequent western blotting using [ ${ }^{125}$ I] IGF-II as the ligand gave bands with estimated molecular weights of $330,220,135,96,46$, $43,34,29$, and $13.5 \mathrm{kDa}$ in one adult, and identical bands at $220,41 \cdot 5,37 \cdot 5,32$, and $19 \mathrm{kDa}$ in three cyst fluid samples from three children with craniopharyngioma.

Conclusions-These results suggest that IGFs and IGF binding proteins are secreted by craniopharyngiomas and that they may alter the growth characteristics of these tumours. Furthermore, the distinct pattern of IGF binding protein sizes might be used as a tool for the differential diagnosis of tumours of the central nervous system.

(f Clin Pathol: Mol Pathol 1996;49:M51-M56)

Keywords: craniopharyngioma, insulin-like growth factors, IGF binding proteins, tumour marker.

Craniopharyngiomas account for about $9 \%$ of all primary childhood brain tumours with a particular high incidence around the age of eight years. ${ }^{1}$ Their location is predominantly suprasellar, either in the pituitary stalk or hypothalamus. It is thought that they arise from Rathke's pouch where high levels of insulinlike growth factor (IGF) II mRNA expression have been detected. ${ }^{2}$

Cyst fluid from malignant brain tumours contains various growth factors, including IGF, that are mitogenic for various cell lines. ${ }^{3-6} \mathrm{In}-$ hibitory factors such as IGF binding proteins have also been identified in cyst fluid. ${ }^{7}$

IGF-I and -II are mitogenic polypeptides and are synthesised by various tissues. In brain, IGF-I is widely distributed, ${ }^{8}$ while IGF-II expression is limited to the plexus choroideus, leptomeninges and the fetal Rathke's pouch. ${ }^{2-12}$ IGFs are bound to specific IGF binding proteins which modulate the effect of IGFs on their target cells. ${ }^{13}$ Of these, IGF binding protein- 2 is the predominant IGF binding protein species in both fetal and adult brain. ${ }^{14}$

The present study was undertaken to evaluate the presence of IGFs and the heterogeneity of IGF binding proteins in cyst fluid samples from patients with craniopharyngioma.

\section{Methods}

Cyst fluid samples were obtained by stereotactic puncture from seven patients (A-G) (age range two to 43 years) with craniopharyngioma prior to an intracavitary injection of ${ }^{90}$ Yttrium $^{15}$ (day 0 ) and at one to three succeeding punctures thereafter (range day 11 to day 1946).

\section{ACID ETHANOL EXTRACTION}

Cyst fluid samples $(100 \mu \mathrm{l})$ were incubated with $400 \mu \mathrm{l}$ acid ethanol $(0 \cdot 15 \% 12 \mathrm{M} \mathrm{HCl})$ for 30 minutes. To neutralise the reaction, $200 \mu \mathrm{l}$ $0.86 \mathrm{M}$ Tris $/ \mathrm{HCl}$ was added and the mixture was centrifuged at $3000 \mathrm{rpm}$ for 20 minutes. An aliquot of $100 \mu \mathrm{l}$ of the supernatant fluid was subsequently analysed by specific radioimmunoassays for IGF-I and IGF-II.

\section{GEL FILTRATION}

The cyst fluid samples $(250 \mu \mathrm{l})$ were acidified with $250 \mu \mathrm{l} 2 \mathrm{~mol} / \mathrm{l}$ acetic acid and loaded onto a Sephacryl S-100 HR column $(38 \times 1 \mathrm{~cm}$; Pharmacia, Uppsala, Sweden) equilibrated with $1 \mathrm{~mol} / 1$ acetic acid ( $\mathrm{pH} 4 \cdot 0) . \mathrm{V}_{0}$ is equivalent to a $K_{d}$ value of 0 and $V_{i}$ to a $K_{d}$ of 1 . 

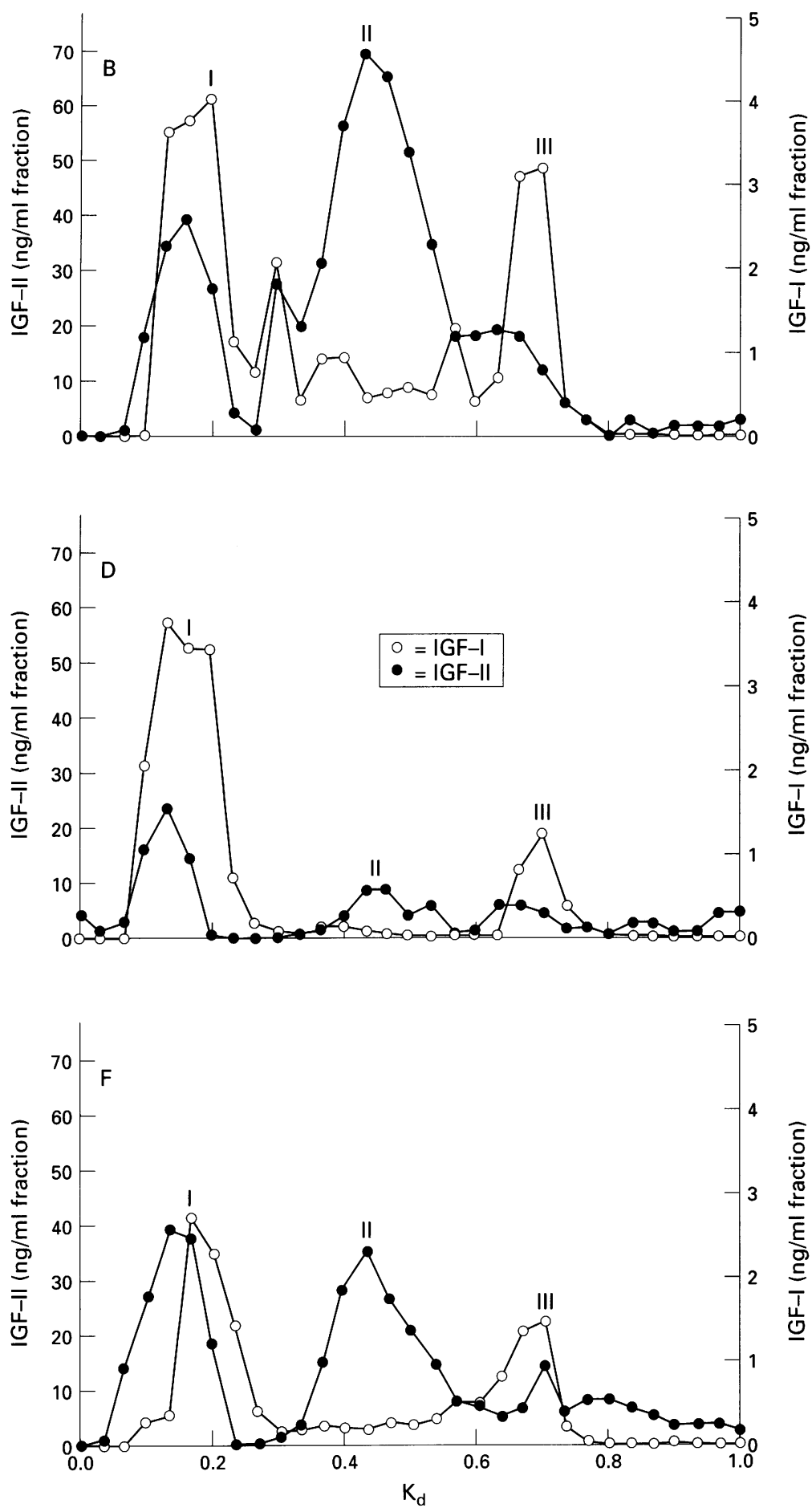

Figure 1 Elution profiles of IGF-1 and -II after acid gel chromatography of craniopharyngioma cyst fluid samples from patients $B, C$ and $F\left(V_{o}=K_{d}\right.$ of 0 and $V_{i}=$ $K_{d}$ of 1 ; peaks are labelled I, II and III).

Labelled IGF binding protein-1 is eluted at a $\mathrm{K}_{d}$ of 0.24 and IGF-I at a $\mathrm{K}_{\mathrm{d}}$ of 0.66 . IGFs were eluted and measured in the $\mathrm{K}_{\mathrm{d}}$ range $0 \cdot 47$ to $0 \cdot 77$.

Immunoreactive IGF-I, IGF-II and IGF binding protein-1 concentrations (ng/ml) in cyst fluid samples from three patients with craniopharyngioma

\begin{tabular}{|c|c|c|c|c|c|c|}
\hline \multirow[b]{2}{*}{ Patient } & \multirow[b]{2}{*}{ Age (years) } & \multirow{2}{*}{$\frac{I G F-I}{G C}$} & \multicolumn{3}{|c|}{$I G F-I I$} & \multirow{2}{*}{$\frac{\text { IGF binding protein- } 1}{U S}$} \\
\hline & & & $G C$ & $A E$ & US & \\
\hline $\begin{array}{l}\text { B } \\
\text { C } \\
\text { F }\end{array}$ & $\begin{array}{l}6 \cdot 6 \\
15 \cdot 8 \\
18 \cdot 2\end{array}$ & $\begin{array}{l}29 \\
6 \\
17\end{array}$ & $\begin{array}{l}404 \\
25 \\
330\end{array}$ & $\begin{array}{l}460 \\
420 \\
320\end{array}$ & $\begin{array}{l}730 \\
800 \\
220\end{array}$ & $\begin{array}{l}48 \\
38 \\
17\end{array}$ \\
\hline
\end{tabular}

$\mathrm{GC}=$ gel chromatography; $\mathrm{AE}=$ acid ethanol extraction; $\mathrm{US}=$ unseparated sample.
BINDING STUDIES

Ten microlitres of cyst fluid were preincubated with labelled des(1-3)-IGF-I, IGF-I or IGF-II and re-run on a Sephacryl S-100 HR column $(29.5 \times 1 \mathrm{~cm})$ equilibrated with $0.05 \mathrm{~mol} / 1$ phosphate buffer ( $\mathrm{pH} 7 \cdot 4)$. Each fraction was counted in a gamma counter and the results were expressed as the percentage of total radioactivity.

\section{RADIOIMMUNOASSAYS}

IGF-I and IGF-II concentrations were measured using specific radioimmunoassays as described previously. ${ }^{4}$ Briefly, polyclonal rabbit antibody (donated by Professor Gluckman, Auckland, New Zealand) directed against recombinant human IGF-I (KabiGen, Stockholm, Sweden) was used in the IGF-I radioimmunoassay (RIA). Des(1-3)-IGF-I was used as a ligand and recombinant hIGF-I as a standard. For IGF-II, a RIA with recombinant hIGF-II (KabiGen) as a standard and hen yolk antibody raised against hIGF-II was used. For IGF binding protein-1, a specific RIA was used as described in detail by Povoa et al. ${ }^{16}$

\section{WESTERN BLOTTING}

Unreduced craniopharyngioma cyst fluid samples from one adult and three paediatric patients $(B, C$ and $F$ ) were subjected to sodium dodecyl sulphate-polyacrylamide gel electrophoresis (SDS-PAGE) using a $12 \cdot 6 \%$ polyacrylamide slab gel $(160 \times 105 \times 1.5 \mathrm{~mm})$ as described by Hossenlopp et al. ${ }^{17}$ The proteins were then transferred onto nitrocellulose sheets and subsequently incubated with [ $\left.{ }^{125} \mathrm{I}\right] \mathrm{IGF}-\mathrm{II}$. The dried nitrocellulose filter was then exposed at $-70^{\circ} \mathrm{C}$ on a Hyperfilm-MP (Amersham, Little Chalfont, UK) for seven days.

\section{Results}

ELUTION PATTERN FOR IGF-I AND IGF-II

Figure 1 shows the elution profiles of IGF-I and IGF-II from three craniopharyngioma cyst fluid samples after acid gel filtration and specific radioimmunoassays. High immunoreactivity was observed for IGFs in the $K_{d}$ range $0 \cdot 0-0 \cdot 3$ (molecular weights $>100 \mathrm{kDa}$ ); immunoreactivity was rather low in the $K_{d}$ range $0 \cdot 6-0 \cdot 8$ where free IGF-I and IGF-II are eluted. High immunoreactivity was also found in the $\mathrm{K}_{\mathrm{d}}$ range $0 \cdot 3-0 \cdot 6$ where the elution of IGF binding proteins occurs.

IGF-I, IGF-II AND IGF BINDING PROTEIN-1 CONCENTRATIONS

IGF-I, -II and IGF binding protein-1 concentrations were measured in three craniopharyngioma samples (table). Immunoreactive IGF-I and IGF binding protein-1 concentrations in three cyst fluid samples ranged between 6 and $29 \mathrm{ng} / \mathrm{ml}$, and 17 and $48 \mathrm{ng} / \mathrm{ml}$, respectively. IGF-II concentrations in two of three samples were about 20 -fold higher than the respective IGF-I concentrations. As clearly demonstrated, it is crucial that separation of 


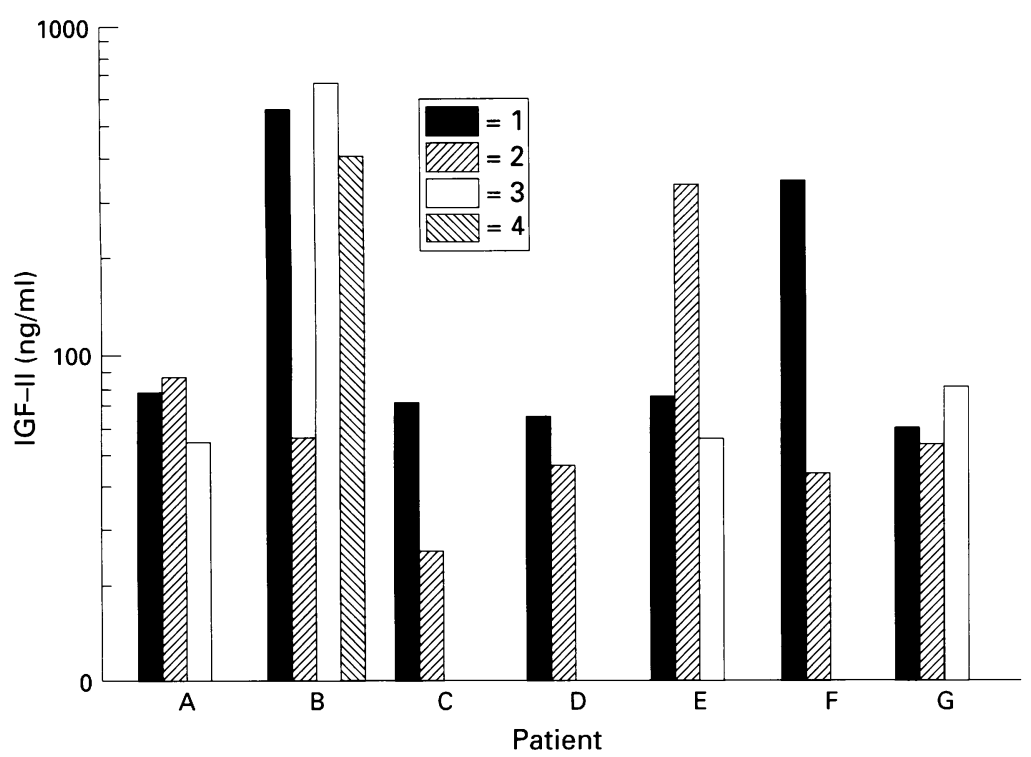

Figure 2 Immunoreactive IGF-II concentrations were measured in a total of 19 cyst fluid samples from seven patients $(A-G)$ before (1) intracavitary irradiation with ${ }^{90} Y$ ttrium and at subsequent punctures thereafter (2-4): patient $A$, days 0,18 and 271; patient $B$, days $0,11,32$, and 449; patient $C$, days 0 and 1946; patient $D$, days 0 and 28 ; patient $E$, days 0,130 and 144 ; patient $F$, days 0 and 131 ; patient $G$, days 0,199 and 335 .
BINDING STUDIES

Chromatography of cyst fluid samples from two patients after preincubation with labelled IGFs yielded three different peaks (fig 3) with $\mathrm{K}_{\mathrm{d}}$ ranges of $0 \cdot 03-0 \cdot 09$ (peak I), $0 \cdot 2-0 \cdot 4$ (peak II) and $0 \cdot 6-0 \cdot 8$ (peak III). IGF-I, des(1-3)IGF-I and IGF-II bound more strongly at peak II than at peak I. When unlabelled IGFs were added, peak II could be displaced and shifted to peak III, increasing the amount of free IGFs. Surprisingly, des(1-3)-IGF-I showed significant affinity to IGF binding proteins and unlabelled peptide could block this binding specifically.

WESTERN BLOTTING

SDS-PAGE and western blotting, using $\left[{ }^{125} \mathrm{I}\right] \mathrm{IGF}-\mathrm{II}$ as a ligand, were carried out on craniopharyngioma cyst fluid samples from one adult and three paediatric patients (B, C and F). Autoradiography revealed bands corresponding to the following molecular weights: $330,220,135,96,46,43,34,29$, and $13 \cdot 5 \mathrm{kDa}$ in the adult and $200,41.5,37.5,32$, and $19 \mathrm{kDa}$ in the paediatric patients (fig 4).

\section{Discussion}

The present study demonstrates the presence of IGFs and IGF binding proteins in the cyst fluid samples from patients with craniopharyngioma.

In addition to our previous results, ${ }^{4}$ there is evidence for the presence of a binding protein capable of binding the truncated form of IGFI. This IGF-I variant lacks three amino acids at the $\mathrm{N}$-terminus and has virtually no affinity for IGF binding proteins. ${ }^{18}$ The binding of des(1-3)-IGF-I is specific as the addition of unlabelled peptide could displace the binding of this truncated IGF-I to the IGF binding protein. The displacement is not absolute, probably due to the addition of insufficient amounts of competitor, but it seems that binding of des(1-3)IGF-I is specific and that it is due to IGF binding proteins with molecular weights of $30-50 \mathrm{kDa}$ and not to IGF receptor proteins, which are eluted at a lower $\mathrm{K}_{\mathrm{d}}$ (peak I). However, this does not preclude the possibility that smaller cleavage products of the IGF-II receptor are responsible for binding of des(13)-IGF-I. Further evaluation of this observation is clearly warranted.

The concentration of IGF-II was up to 20fold higher than the respective IGF-I concentrations. Furthermore, the IGF-II concentrations in the craniopharyngioma cyst fluid samples were significantly higher than those found in astrocytoma and prolactinoma cyst fluid samples. ${ }^{56}$ It is possible that craniopharyngioma cells synthesise considerable amounts of IGF-II as high levels of IGF-II mRNA expression have been found in the epithelial components of Rathke's pouch in the rat fetus. ${ }^{2}$ Moreover, fetal brain expresses higher levels of IGF-II mRNA compared with adult brain, where expression is restricted to the choroid plexus and leptomeninges. ${ }^{101920}$ We suggest that measurement of the concentration patients a decrease in IGF-II concentratior was observed at a subsequent puncture. In two patients the decrease in IGF-II concentrations did not persist and a further increase was observed at subsequent punctures. 

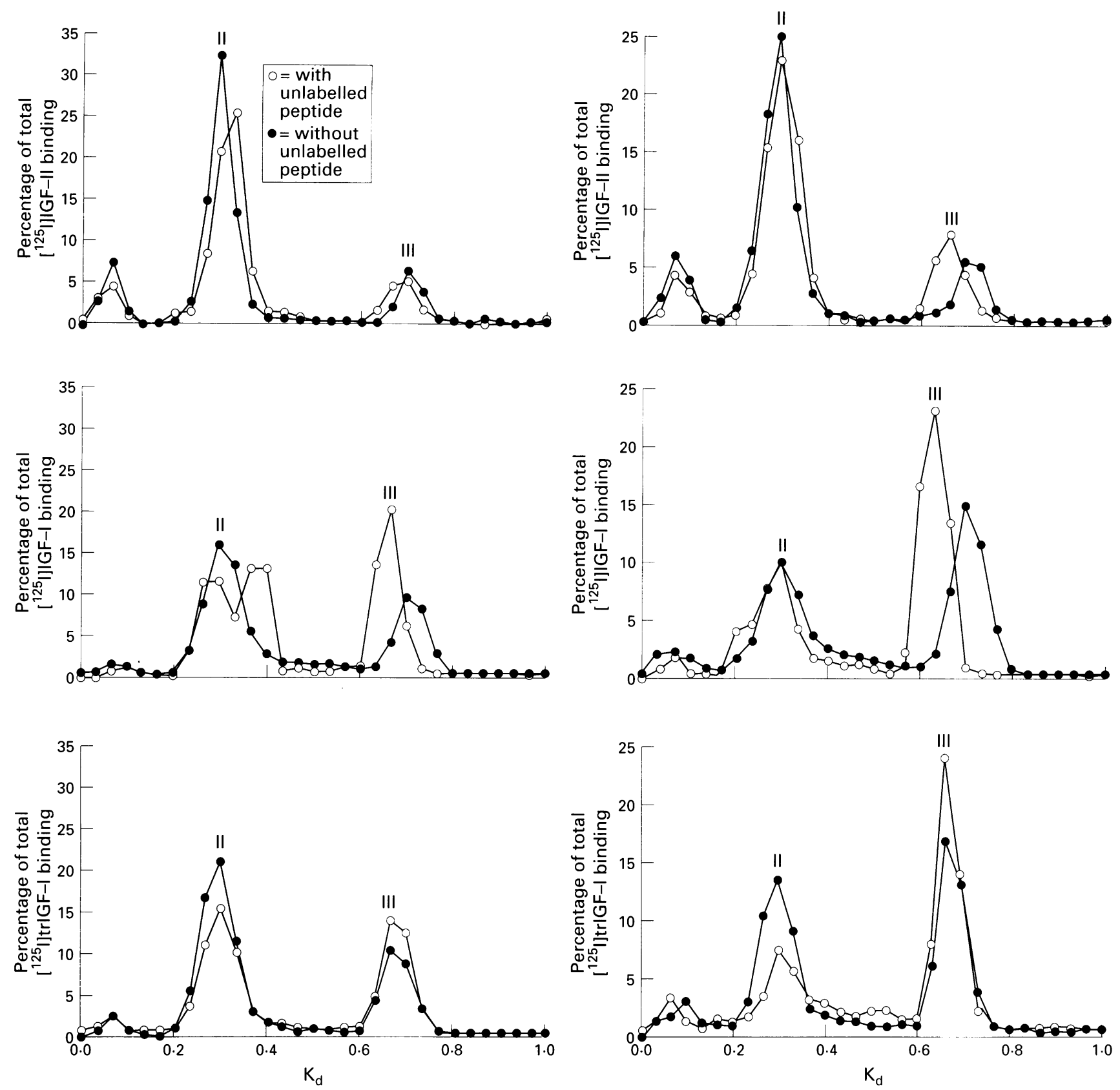

Figure 3 Gel chromatography at neutral pH of two cyst fluid samples preincubated with [ ${ }^{125}$ IJtrIGF-I, [ ${ }^{25}$ IJIGF-I or [125IJIGF-II with or without unlabelled peptide. $V_{v}=K_{d}$ of 0 and $V_{i}=K_{d}$ of 1 ; peaks are labelled I, II and III.

of IGF-II in craniopharyngioma cyst fluid may be useful for the differential diagnosis of other brain tumour cysts - for example, prolactinoma and glioma.

Although the concentration of immunoreactive IGF binding protein-1 in these cysts is low, craniopharyngiomas seem to synthesise other IGF binding proteins in considerable abundance. Preliminary immunohistochemical data showed weak staining for IGF binding protein-2 and IGF binding protein-5, strong staining for IGF binding protein-3 and none for IGF binding protein-1 (Zumkeller et al, unpublished data, 1995). IGF binding protein2 seems to be the predominant IGF binding protein in the central nervous system and its level of expression in the fetal rat brain stem, cerebral cortex and hypothalamus is much higher than that of IGF binding protein-1. ${ }^{21}$ Expression of IGF binding protein-2 mRNA has also been found in the choroid plexus of adult rats. ${ }^{22}$ Thus, the observed low immunoreactivity for IGF binding protein-1 in our cyst fluid samples concurs with the immunohistochemical data. These results also indicate that various other IGF binding proteins are secreted by craniopharyngiomas.

The IGF binding protein pattern on western blotting differs in cyst fluid samples from adults and children with craniopharyngiomas. The bands were identical in all three paediatric cyst fluid samples, with a major band at $37 \cdot 5 \mathrm{kDa}$. In the adult craniopharyngioma cyst fluid sample, the major band was at $46 / 43 \mathrm{kDa}$, possibly IGF binding protein-3. Bands at 45,40 and $36.5 \mathrm{kDa}$ were also described in cultured rat astroglial and neuronal cells. ${ }^{923}$ A $34 \mathrm{kDa}$ band was also found in astrocytoma ${ }^{5}$ and prolactinoma cyst fluid samples, ${ }^{6}$ which could be identical with the one detected in cerebrospinal 


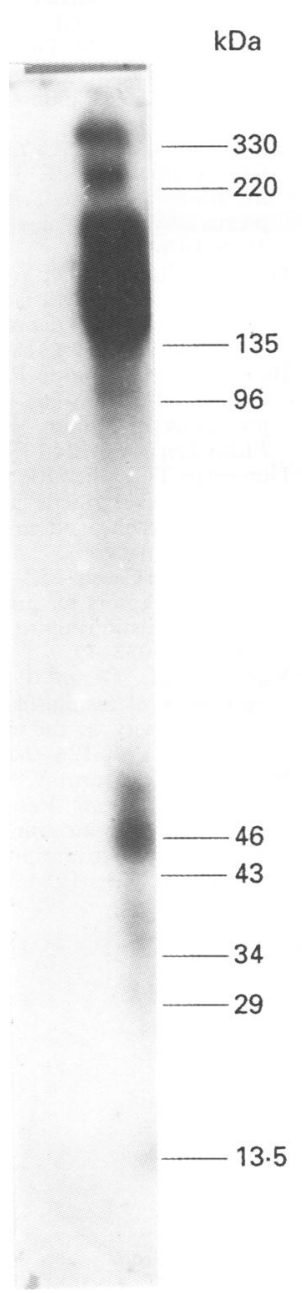

A

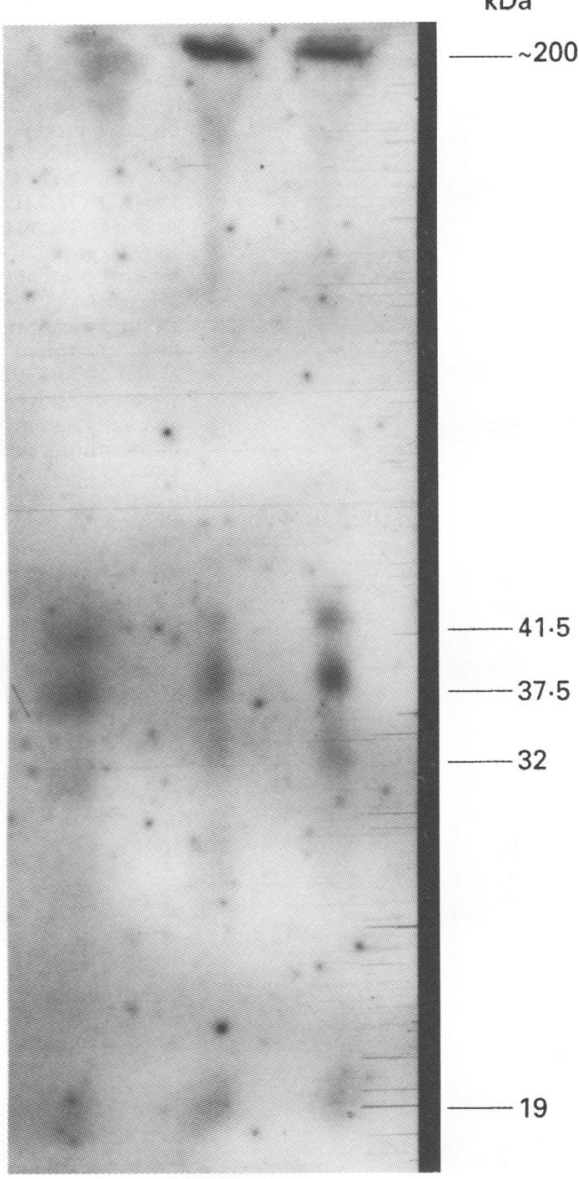

Figure 4 SDS-PAGE and western blotting of craniopharyngioma cyst fluid samples from an adult $(A)$ and three children (B) using labelled IGF-II (lanes $A-C$, patients $B, C$ and $F$, respectively). Low and high molecular weight markers (Pharmacia) were used.

fluid and human fetal cerebral cortex. ${ }^{24}$ Malignant gliomas synthesise an IGF binding protein with a molecular weight of $35 \mathrm{kDa}$ (shown to be IGF binding protein-2) in addition to a $24 \mathrm{kDa}$ form $^{25}$ which was not present in our samples. We have also found bands at 19 and $13.5 \mathrm{kDa}$, which have not been described before but fetal neurons have been reported to synthesise a $23 \mathrm{kDa}$ IGF binding protein, ${ }^{14}$ which might be related to our $19 \mathrm{kDa}$ form.

The high molecular weight bands at 330 , $220,200,135$, and $96 \mathrm{kDa}$ may represent subunits, truncated forms, monomers, or dimers of IGF receptors. The 220 and $200 \mathrm{kDa}$ bands may reflect a truncated form of the type II IGF receptor whereas the 135 and $96 \mathrm{kDa}$ bands may represent type I IGF receptor subunits. ${ }^{26}$ The IGF-II receptor is widely distributed in the pituitary and choroid plexus of fetal and adult rats. ${ }^{27}$ Bands of this size are consistently found in the cyst fluid of other brain tumours. ${ }^{56}$

In conclusion, stereotactic intracavitary irradiation with ${ }^{90}$ Yttrium or ${ }^{186}$ Rhenium has been widely carried out in patients with cystic craniopharyngiomas. ${ }^{1529}$ A reduction in the content of IGF-II in the cyst fluid after intracavitary irradiation may indicate a good re- sponse to such a treatment. Monitoring the cyst fluid IGF-II concentrations may provide an additional parameter with which to judge the success of treatment.

1 Bingas B, Wolter M. Das Kraniopharyngiom. Fortschr Neurol Psychiatr 1968;36:117-95.

2 Ayer-Le Lievre C, Stahlbom PA, Sara VR. Expression of IGF-I and II mRNA in the brain and cranio-facial region of the rat fetus. Development 1991;111:105-15.

3 Westphal M, Nausch H, Herrmann HD. Cyst fluids of malignant human brain tumors contain substances that stimulate the growth of cultured human gliomas of various histological type. Neurosurgery 1989;25:196-201.

4 Zumkeller W, Sääf $M$, Rähn T, Hall K. Demonstration of insulin-like growth factors I, II and heterogeneous IGFbinding proteins in the cyst fluid of patients with craniobinding proteins in the cyst fluid of patients with cran
pharyngioma. Neuroendocrinology 1991;54:196-201.

5 Zumkeller W, Sääf M, Rähn T. Insulin-like growth factor (IGF)-I, -II and IGF-binding proteins in the cyst fluid of (IGF)-I, -II and IGF-binding proteins in the cyst fluid of
a patient with astrocytoma. Childs Nerv Syst 1993;9:100-3.

6 Zumkeller W, Sääf M, Rähn T. Insulin-like growth factors (IGF)-I and -II and IGF-binding proteins in the prolactinoma cyst fluid. Onkologie 1994;17:600-3.

7 Westphal M, Zumkeller W. Insulin-like growth factor-binding protein-1 and -3 in cyst fluids of human intracranial tumours [abstract]. 3rd International Symposium on Insulin-like Growth Factors, Sydney, Australia, February 6-10, 1994. Growth Regul 1994;4(Suppl 1):224.

8 Sara VR. The role of the insulin-like growth factors in the nervous system. In: Schofield PN, Tate V, eds. The insulinlike growth factors: structure and function. Oxford: Oxford University Press, 1992:258-79.

9 Han KM, D'Ercole AJ, Lund PK. Cellular localization of somatomedin (insulin-like growth factor) messenger RNA in human fetus. Science 1987;236:193-7.

10 Hynes MA, Brooks PJ, Van Wyk JJ, Lund PK. Insulin-like growth factor II messenger ribonucleic acids are syn- 
thesized in the choroid plexus of rat brain. Mol Endocrinol $1988 ; 2: 47-54$

11 Stylianopoulou F, Herbert J, Soares MB, Efstratiadis A. Expression of the insulin-like growth factor-II gene in the choroid plexus and leptomeninges of the adult rat central nervous system. Proc Natl Acad Sci USA 1988;85:141-5.

12 Stylianopoulou F, Efstratiadis A, Herbert J, Pintar J. Pattern of insulin-like growth factor II gene expression during rat embryogenesis. Development 1988;103:497-506.

13 McCusker RH, Clemmons DR. Insulin-like growth factor binding proteins: structure and biological functions. In Schofield PN, Tate V, eds. The insulin-like growth factors, structure and biological functions. Oxford: Oxford University Press, 1992:110-50.

14 Lamson G, Pham H, Oh Y, Ocrant I, Schwander J, Rosenfeld RG. Expression of the BRL-3A insulin-like growth factor binding protein $(\mathrm{rBP}-30)$ in the rat central nervous system. Endocrinology' 1989;123:1100-2.

15 Backlund EO. Studies on craniopharyngioma. III. Stereotaxic treatment with intracystic yttrium-90. Acta Chi Scand 1973;139:237-47.

16 Povóa G, Enberg G, Jörnvall $\mathrm{H}$, Hall K. Isolation and characterization of a somatomedin-binding protein from midterm human amniotic fluid. Eur 7 Biochem 1984;144 199-204.

17 Hossenlopp P, Seurin D, Segovia-Quinson B, Hardouin S, Binoux $M$. Analysis of serum insulin-like growth factor binding proteins using Western blotting: Use of the method for titration of the binding proteins and competitive bindfor titration of the binding proteins and compet
ing studies. Anal Biochem 1986;154:138-43.

18 Sara VR, Carlsson-Skwirut C, Andersson C, Hall K, Sjögren B, Holmgren A, ot al. Characterization of somatomedins from human fetal brain: identification of a variant form of insulin-like growth factor I. Proc Natl Acad Sci USA 1986;83:4904-7.

19 Lund PK, Moats-Staats BM, Hynes MA, Simmons JG, Jansen M, D'Ercole AJ, ct al. Somatomedin-C/insulin-like growth factor-I and insulin-like growth factor-II mRNAs in rat fetal and adult tissues. F Biol Chem 1986;261. $14539-44$.
20 Beck F, Samani NJ, Byrne S, Morgan K, Gebhard R, Brammar WJ. Histochemical localization of IGF1 and IGF2 mRNA in the rat betwe
Development 1988;104:29-39.

21 Ooi GT, Orlowski CC, Brown AL, Becker RE, Unterman TG, Rechler MM. Different tissue distribution and hormonal regulation of messenger RNAs encoding rat insulinlike growth factor-binding protein-1 and -2. Mol Endocrinol 1990;4:321-8.

22 Tseng LYH, Brown AL, Yang YWH, Romanus JA, Orlowski $\mathrm{CC}$, Taylor $\mathrm{T}$, et al. The fetal rat binding protein for insulin-like growth factors is expressed in the choroid plexus and cerebrospinal fluid of adult rats. Mol Endocrinol plexus and cerebrosp

23 Ocrant I, Pham H, Oh Y, Rosenfeld RG. Characterization of insulin-like growth factor binding proteins of cultured rat astroglial and neuronal cells. Biochem Biophys Res Commun 1989;159:1316-22.

24 Binoux M, Hossenlopp P, Lassarre C, Hardouin N. Production of insulin-like growth factors and their carrier protein by rat pituitary gland and brain explants in culture. FEBS Lett 1986;124:178-84.

25 Unterman TG, Glick RP, Waites GT, Bell SC. Production of insulin-like growth factor-binding proteins by human central nervous system tumours. Cancer Res 1991;51: 3030-6.

26 Massagué J, Czech MP. The subunit structures of two distinct receptors for insulin-like growth factors I and II and their relationship to the insulin receptor. 7 Biol Chem 1982;257:5038-45.

27 Valentino KL, Ocrant I, Rosenfeld RG. Developmental expression of insulin-like growth factor-II receptor immunoreactivity in the rat central nervous system. Enmunoreactivity in the rat cent
docrinology 1990;126:914-20.

28 Netzeband G, Sturm V, Georgi P, Sinn H, Schnabel K, Schlegel W, et al. Results of stereotactic intracavitary irradiation of cystic craniopharyngiomas. Comparison of the effects of Yttrium-90 and Rhenium-186. Acta Neurochir Suppl (Wien) 1984;33:341-4. 